\title{
Neural Progestin Receptors and Female Sexual Behavior
}

\author{
Shaila K. Mani ${ }^{a}$ Jeffrey D. Blaustein ${ }^{b}$ \\ ${ }^{a}$ Department of Molecular and Cellular Biology, Department of Neuroscience, Center on Addiction, \\ Learning and Memory, Baylor College of Medicine, Houston, Tex., and ${ }^{b}$ Neuroscience and Behavior Program and \\ Center for Neuroendocrine Studies, University of Massachusetts, Amherst, Mass., USA
}

\section{Key Words}

Progesterone $\cdot$ Progestin receptors $\cdot$ Dopamine $\cdot$ Crosstalk

\begin{abstract}
The steroid hormone, progesterone $(\mathrm{P})$, modulates neuroendocrine functions in the central nervous system resulting in integration of reproduction and reproductive behaviors in female mammals. Although it is widely recognized that P's effects on female sex behavior are mediated by the classical neural progestin receptors (PRs) functioning as 'ligand-depen-

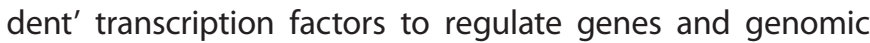
networks, additional mechanisms of PR activation also contribute to the behavioral response. Cellular and molecular evidence indicates that PRs can be activated in a ligand-independent manner by neurotransmitters, growth factors, cyclic nucleotides, progestin metabolites and mating stimuli. The rapid responses of $\mathrm{P}$ may be mediated by a variety of PR types, including membrane-associated PRs or extranuclear PRs. Furthermore, these rapid nonclassical $\mathrm{P}$ actions involving cytoplasmic kinase signaling and/or extranuclear PRs also converge with classical PR-mediated transcription-dependent pathways to regulate reproductive behaviors. In this review, we summarize some of the history of the study of the role of PRs in reproductive behaviors and update the status of PR-mediated mechanisms involved in the facilitation of female sex behavior. We present an integrative model of PR activation via crosstalk and convergence of multiple signaling pathways.
\end{abstract}

Copyright $\odot 2012$ S. Karger AG, Basel

\section{KARGER}

Fax +4161306 1234

E-Mail karger@karger.ch

www.karger.com
(C) 2012 S. Karger AG, Basel

$0028-3835 / 12 / 0962-0152 \$ 38.00 / 0$

Accessible online at:

www.karger.com/nen

\section{Introduction}

The dominant, model system for studying the cellular mechanisms of progesterone action in the brain remains the estradiol $\left(\mathrm{E}_{2}\right) /$ progesterone $(\mathrm{P})$ induction of female sexual behavior in guinea pigs, rats and mice. In the 1930s, a series of experiments performed by W.C. Young and his collaborators [1-4] demonstrated that female sexual behavior in both rats and guinea pigs required the sequential exposure to $\mathrm{E}_{2}$ followed a day or two later with P. These findings were subsequently corroborated in mice [5]. To understand the importance of this work, which provided the model used by many research groups, it is necessary to bear in mind that these studies preceded the availability of chemical tools for assaying blood levels of steroid hormones. The findings that $\mathrm{P}$ was essential were not widely accepted [6] because sexual behavior is expressed during the estrous cycle prior to ovulation. However, $\mathrm{P}$ was believed to be secreted only by the corpus luteum, a structure that is formed at the time of ovulation. This work predicted the discovery of $\mathrm{P}$ secretion from the ovaries prior to ovulation, which was confirmed three decades later by gas chromatography $[7,8]$ followed by radioimmunoassay $[9,10]$.

Early hypotheses of P's cellular mechanisms suggested that $\mathrm{P}$ acted by a nonreceptor-mediated mechanism. It was originally believed that for P to act as quickly as it had been shown to facilitate female sexual behavior after in- 
travenous injection in rats $(<10 \mathrm{~min}[11] ;<30 \mathrm{~min}$ [12]; 30 min $[13,14])$, the hormone probably acted via a mechanism distinct from that of $\mathrm{E}_{2}$ [15], probably by a general membrane stabilization mechanism.

\section{Progesterone Action in Brain}

Although earlier signs from studies using in vivo uptake, in vitro binding and autoradiographic techniques using radioactively labeled progestins indicated that neural progestin receptors (PRs), which are similar to the previously characterized neural estrogen receptors (ERs), exist in some brain areas [16-22], studies of the physiological and behavioral relevance of the receptors began in earnest with the work of MacLusky and McEwen [23] in 1978. Using a novel in vitro binding assay for brain PRs, these investigators demonstrated that PRs, physicochemically similar to those in peripheral reproductive tissues, were induced by $\mathrm{E}_{2}$ in some brain areas of rats (pooled hypothalamus-preoptic area-septum), and independent of $E_{2}$ in other areas, including the cerebral cortex and amygdala.

Shortly after the characterization of these receptors in rats, a close relationship was reported between $\mathrm{E}_{2}$-induced PRs in the pooled hypothalamus-preoptic area-septum, midbrain and hypothalamus, and P-facilitated behavioral responsiveness in rats and guinea pigs [24-29]. To summarize, when PRs in guinea pig or rat brain are elevated by $E_{2}$, animals respond to $P$; when they are depressed by prior $\mathrm{P}$ treatment, they are less responsive (sequential inhibition/refractoriness). This suggested that PRs are essential for mediating both the facilitatory and inhibitory effects of $\mathrm{P}$ on female sexual behavior in guinea pigs and rats. Behavioral refractoriness to $\mathrm{P}$ is thought to involve degradation of $\mathrm{PRs}$ by $26 \mathrm{~S}$ proteosome activity within the hypothalamus and preoptic area (POA) [30].

At the time of the characterization of neural PRs, it was widely held that unoccupied steroid hormone receptors were localized in the cytoplasm of cells, and the binding of ligand caused translocation to the cell nucleus where these occupied receptors could be measured by binding assays. It was subsequently reported that many steroid receptors, including unoccupied receptors, reside in the cell nucleus [31, 32]. The development of an assay for what were then called 'nuclear PRs,' but should more appropriately be referred to as 'occupied PRs', led to the observation that the animal's behavioral response to $\mathrm{P}$ was dependent on the level of hypothalamic, occupied PRs [13, 33-36].

Progestin Receptors in Sex Behavior
Autoradiographic techniques provided better anatomical resolution than in vitro ligand-binding techniques, albeit with low sensitivity. $\left[{ }^{3} \mathrm{H}\right]$ Progestin-binding was detected in parts of the POA, including its suprachiasmatic and periventricular aspect, as well as the ventromedial nucleus of the hypothalamus (VMN) and arcuate nucleus in rats [37, 38] and guinea pigs [21, 22].

The punch microdissection technique provided reasonable anatomical resolution as well as good sensitivity $[39,40]$. With this technique, the regions with the highest abundance of $E_{2}$-induced PRs were the arcuate nucleus, the $\mathrm{VMN}$, periventricular POA, the periventricular hypothalamus, the suprachiasmatic POA and the medial preoptic area (MPOA). Each of these areas also has a high concentration of ERs [41], and the list includes areas important in the regulation of female sexual behavior.

The advent of immunocytochemical techniques for PRs $[42,43]$ provided greater precision in the localization of the progestin-responsive cells. Consistent with the earlier findings that a subset of PRs was $\mathrm{E}_{2}$-induced, virtually all cells in which PR-immunoreactivity (-ir) is dependent on $\mathrm{E}_{2}$ also have ERs $[44,45]$. $\mathrm{E}_{2}$-induced PRs were seen in a variety of brain areas in guinea pigs related to reproduction and reproductive behavior, including the bed nucleus of stria terminalis, periventricular preoptic regions, medial preoptic nucleus, MPOA, ventrolateral nucleus of the hypothalamus (homologous with the VMN in rats), lateral hypothalamus, premammillary nucleus, arcuate nucleus [43, 46, 47], and the midbrain central gray and tegmentum [46]. Other PRcontaining areas include the peripeduncular region, parabrachial nucleus of guinea pigs [46] and the hippocampus of rats $[48,49]$. It is important to note that many of the PR-ir cells in the ventrolateral area of the hypothalamus in guinea pigs $[43,50]$ and in the $\mathrm{VMH}$ in other species that we have examined (Blaustein, unpubl. observations) lie outside of the Nissl-defined nuclei. In guinea pigs, they extend upwards in a crescent in proximity to the fornix.

A recent comprehensive analysis of the localization of PR mRNA by in situ hybridization (ISH) in $\mathrm{E}_{2}$-treated, ovariectomized rats found the highest levels of PRs in some of the neural areas that are believed to be involved in reproduction or reproductive behaviors, including the medial nucleus of the amygdala, anteroventral periventricular nucleus, arcuate nucleus, MPOA, median preoptic nucleus, anterior hypothalamic area, VMN and periaqueductal gray [51]. Numerous other areas not directly involved in reproduction have high levels, including the CA3 pyramidal layer of the hippocampus, zona incerta,

Neuroendocrinology 2012;96:152-161 
Fig. 1. Structure and functional organization of PR (a) and isoforms (b). a PR has a conserved DNA-binding domain (DBD) and a ligand-binding domain (LBD) connected by a hinge region $(\mathrm{H})$. The $\mathrm{N}$-terminal region contains a transactivation function 1 (AF1) and the LBD contains the AF2 domain. AF3, present in the N-terminal domain is unique to the PR-B isoform. b Schematic representation of PR isoforms and splice variants. The classical PR gene is composed of 8 exons with a 3,100-bp coding region and $5^{\prime}$ - and $3^{\prime}$-untranslated regions. $\mathrm{PR}-\mathrm{B}$ and $\mathrm{PR}-\mathrm{A}$ isoforms are transcribed from two alternate transcription initiation sites. BUS = B-upstream segment.

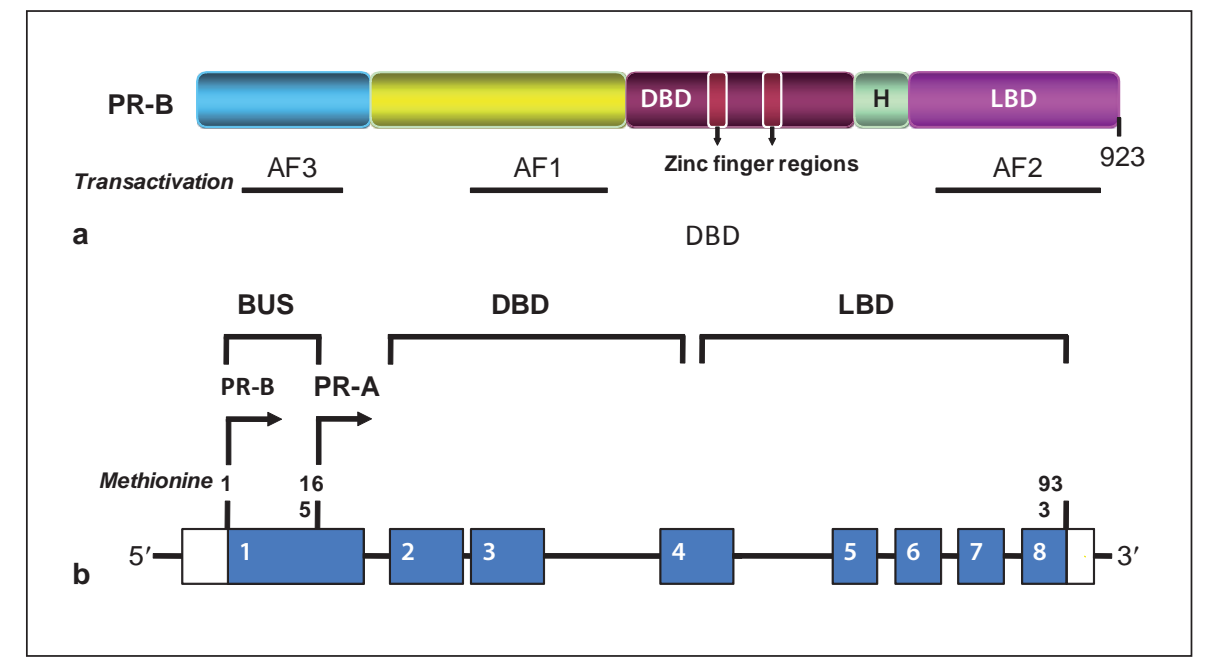

interpeduncular nucleus, and nucleus of the oculomotor cranial nerve, and many other areas have moderate levels of PR mRNA (the reader is referred to table 1 of Intlekofer and Petersen [51] for a comprehensive analysis).

The PR is expressed in two isoforms, PR-A and PR-B, which are synthesized from alternate estrogen-inducible promoters on the same gene, as well as alternate transcription start codons (fig. 1) [52, 53]. Tools used in the experiments discussed thus far could not discriminate between these two isoforms because they bind progestins with equal affinity and are identical with the exception of 164 amino acids on the amino-terminus of PR-B that is absent from PR-A [54]. Relatively little is known about the role of each isoform in brain. However, the two isoforms are expressed in the rat brain [55], and that the ratio of the two isoforms varies under different hormonal [56-59] and mating [60] conditions. Mani et al. [61] used PR isoform-specific knockout strains of mice to determine the relative contribution of each isoform to P-facilitated female sexual behavior. P-facilitated lordosis was completely eliminated in the PR-A null mutant mouse. PR-B null mutant mice showed a trend of suppression of P-facilitated sexual behavior. Collectively, the data suggest that PR-A is essential for P-facilitated lordosis, and both isoforms are required for optimal facilitation by $\mathrm{P}$.

Although PRs bind directly to hormone-response elements on the promoters of target genes, PRs, like other steroid hormone receptors, do not act alone. Rather, a complex of coregulators (coactivators that enhance gene expression and corepressors that repress it) interacts to fine-tune gene expression [62]. Since the characterization of the first steroid hormone receptor coactivator, steroid receptor coactivator-1 (SRC-1), in 1995 [63], over 300 coregulators have been discovered [62]. Very few of these coregulators have been studied within the context of ER or PR action in the brain; however, a decrease in SRC-1 expression by infusion of antisense oligonucleotides into the brain decreases the expression of $E_{2}$-induced PR-ir in the $\mathrm{VMH}$ and the expression of female sexual behavior [64]. SRC-1 and another coactivator, CREB-binding protein, influence the activity of both ER $\alpha$ and PR [65] in the hormonal regulation of female sexual behaviors. Furthermore, SRC-1 from either the hypothalamus or hippocampus, interacts in pull-down assays with ligand-occupied $\mathrm{ER} \alpha, \mathrm{ER} \beta, \mathrm{PR}-\mathrm{A}$ and $\mathrm{PR}-\mathrm{B}$ in a receptor-specific and brain region-specific manner [66], perhaps helping to explain some of the diverse actions of steroid hormones on the brain. A related coactivator, SRC-2, from the hypothalamus and hippocampus interacted with ligand-occupied $\mathrm{ER} \alpha$ and PR-B in pull-down assays, but had very little interaction with ER $\beta$ and did not interact with PR-A [67].

In order for these coactivators to influence steroid receptor action directly and thereby influence reproductive behaviors, the coactivators must be coexpressed in cells containing steroid hormone receptors in brain areas involved in reproductive behaviors. SRC-1-ir is present in most cells containing estradiol-induced PRs in the VMN, MPOA and arcuate nucleus, and many in the midbrain central gray [68]. Most cells containing $\mathrm{E}_{2}$-induced PRs in these areas also express CREB-binding protein-ir. SRC-2 is also highly expressed within these regions [67] and is expressed in many ER $\alpha$-ir cells (many of which are likely to coexpress PR-ir). Thus, coactivators confer another, complex level of fine-tuning of steroid hormone 
response systems. Response to $\mathrm{P}$ is dependent not only on the presence of sufficient levels of PRs in relevant cells, but is also dependent upon and fine-tuned by the coexpression of a variety of steroid receptor coactivators.

Like ER-ir [69], PR-ir is observed in both cell nuclear and extranuclear sites [43] within hypothalamic areas, suggesting extranuclear sites of action as well as the classical nuclear site. The notion that ERs and PRs were shunted to distal subcellular sites was supported by work showing that the microtubule inhibitor, colchicine, induced the appearance of ER-ir and PR-ir in some brain areas in which they were not typically seen [70]. These extranuclear receptors may represent receptors en route to membrane sites and may explain some of the reported membrane effects of $\mathrm{P}$ on sexual behavior [71].

\section{Ligand-Independent Action of Progestin Receptors}

Although P-dependent activation of neural PRs remains the prevalent model in the regulation of female sexual behavior, alternate mechanisms by which PRs can be indirectly activated cannot be ignored. As early as the 1970s, nonsteroidal agents, gonadotropin-releasing hormone (GnRH; [72]) and prostaglandins $\left(\mathrm{PGE}_{2} ;\right.$ [73]) were shown to influence female sexual behavior in rodents, independent of P. Subsequent studies demonstrated that a large number of peptide hormones (e.g. oxytocin, melanocyte stimulating hormone, prolactin, adenocorticotropic hormone), neurotransmitters (e.g. noradrenaline, dopamine, acetylcholine, $\gamma$-aminobutyric acid) and cyclic nucleotides also facilitate female sexual behavior (reviewed in [74-76]). In this context, it is interesting to note that levels of hypothalamic GnRH, $\mathrm{PGE}_{2}$, oxytocin and dopamine peak in estrous cycling rats concurrently with the rise in $\mathrm{P}$ levels, i.e. at about the time that the animal exhibits sexual behavior [77-81]. However, unlike $P$, these agents do not bind to PRs. Instead, they act on G-proteincoupled membrane receptors to elevate hypothalamic levels of second messengers (cyclic AMP, cyclic GMP, calcium), suggesting that alternate pathways mediated by second messengers indirectly influence female sex behavior [74]. We now know that such second messengers can substitute for $P$ in the facilitation of female sex behavior [82]. These observations do not diminish the importance of the classical mechanism through which P-activated neural PRs mediate transcription-dependent genomic actions to influence sexual behavior. Indeed, studies using PR antagonists, protein and RNA synthesis inhibitors [83-86], antisense oligonucleotides to PR [87-
89], and mutant mice with targeted deletion of PR gene [90] provide substantial proof that PR-mediated classical mechanism plays an important role in the facilitation of female sexual behavior.

Studies demonstrating that factors other than its cognate ligands can activate PRs have led to a better understanding of the mechanisms involved in the regulation of female sex behavior. This mechanism, termed 'ligand-independent activation', was first demonstrated in dopamine facilitation of sexual behavior. Although it was known that dopamine could substitute for $\mathrm{P}$ in the facilitation of female sexual behavior [91], the demonstration that this behavior involved ligand-independent activation of PRs by dopamine provided the molecular underpinnings for the observed effects and highlighted a great degree of crosstalk between P- and dopamine-initiated pathways [90, 92].

Using biochemical and molecular tools, Mani et al. [93] demonstrated that both $\mathrm{P}$ and dopamine initiate second messenger signaling cascades involving increases in $3^{\prime}-5^{\prime}$ cyclic adenosine mono phosphate (cAMP) levels, activation of protein kinase A (PKA) and phosphorylation of neuronal phosphoprotein, dopamine and cAMP-regulated phosphoprotein-32 (DARPP-32), leading to the alterations in phosphorylation dynamics and activation of PRs and/or its coregulators in the hypothalamus. Homozygous mice carrying a null mutation for the DARPP-32 gene exhibited significantly reduced P- and dopamine-facilitated female sexually receptive behavior compared to their wild-type littermates, reinforcing the obligatory role of DARPP-32 in the PR-mediated ligand-independent activation mechanism [93]. While the observations indicate that DARPP-32 activation is an obligatory step in PR regulation of sexual receptivity, the subsequent sequence of events leading to the activation of PR have yet to be defined. It is likely that the mechanisms include not only a direct phosphorylation and activation of PR, but also enhanced phosphorylation of a distinct, yet diverse, set of PR-associated coactivators leading to rapid efficient transcriptional activation [54, 94-97]. Furthermore, ligand-independent activation by dopamine requires the expression of both PR-A and PR-B isoforms since both PR-A and PR-B mutant mice displayed reduced female sexual behavior [61].

Ligand-independent activation of PRs is also observed in other physiological processes associated with female sexual behavior. Mating-related stimuli induced by copulatory attempts by a male rodent, or manually by the experimenter, activate PRs in the absence of P [98-101]. Since mating stimulation induces dopamine release [102105] and immediate early gene response (Fos) in PR-con- 
taining neurons [106], it is possible that dopamine activates PRs via a ligand-independent activation mechanism. Ligand-independent activation of PRs also appears to play a role in vaginocervical stimulation (VCS)-, GnRH-, $\mathrm{PGE}_{2^{-}}, \delta$-opioid-, nitric oxide- and $\alpha_{1}$-adrenergic receptor-facilitation of sexual behavior in rats since PR antagonists inhibit the behavior [107-111]. Thus, ligand-independent activation of PRs by nonligands, involving crosstalk with second messenger cascades, appears to be a common mechanism mediating female sex behavior in rats and mice and is discussed in the following sections.

\section{Nonclassical Mechanisms of Progesterone Action}

$\mathrm{P}$ also exhibits short-latency effects via modulation of putative cell surface PR receptors, ion channels and mechanisms coupled to cytoplasmic second messenger signaling cascades, independent of gene transcription $[75,112,113]$. Since these nonclassical effects occur rapidly (in seconds or minutes) and are triggered at the membrane surface, the classical model of nuclear PR-mediation is inadequate to explain these effects. The identification of two types of novel membrane proteins unrelated to classical PRs, membrane PRs (mPRs) and progesterone receptor membrane component 1 (PGRMC1) in the brain suggests the possibility of these proteins in mediating effects [51, 114-117]. mPRs, originally discovered in teleost ovaries, are G-protein-coupled receptors, which belong to the seven transmembrane adiponectin $\mathrm{Q}$ receptor (PAQR) family and are composed of at least three subtypes: $\alpha, \beta$ and $\gamma[118,119]$. PGRMC1 (25Dx), a single transmembrane protein, was originally isolated from porcine liver membranes [120] and has been shown to be regulated by $\mathrm{E}_{2}$ and $\mathrm{P}$ in the $\mathrm{VMH}$ of female rat [121].

Real-time reverse transcriptase-polymerase chain reaction (RT-PCR) and ISH studies indicate that both these membrane proteins are present in the rat brain. Sleiter et al. [115] have reported the presence of $\mathrm{mPR} \alpha$ and $\mathrm{mPR} \beta$ messages in the medial basal hypothalamus. mRNA levels of PRB, mPR $\alpha$ and $\mathrm{mPR} \beta$, but not of mPR $\gamma$ and PGRMC1 levels, are elevated in the mediobasal hypothalamus on the afternoon of proestrus, around the time of preovulatory peak of $\mathrm{P}$ in cycling rats, suggesting that $\mathrm{P}$ action could involve both rapid and classical genomic mechanisms around that period [117]. In contrast, neuroanatomical distribution studies using ISH demonstrated low and homogenous expression of mPRs in the hypothalamus and robust expression in the thalamic nuclei and cortex of estradiol-treated, ovariectomized female rat. In addition, PGRMC1, PGRMC2 and classical PR mRNAs were highly expressed and displayed extensive overlap in the preoptic and hypothalamic nuclei and their projection sites [51]. Furthermore, using real-time RTPCR, Intlekofer and Peterson [116] also demonstrated that $\mathrm{P}$ treatment resulted in a significant increase in PGRMC1 mRNA levels in the ventrolateral region of VMN and sexually dimorphic nucleus of the POA, the areas known to be involved in female sexual behavior. While the functional role of these putative membrane receptors remains to be determined, the findings suggest possible interactions of membrane PRs and classical PRs within the same neurons in mediating the effects of $P$.

In addition to the factors discussed above, ring- $\mathrm{A}$ reduced metabolites of $\mathrm{P}, 5 \alpha$-dihydroprogesterone and allopregnanolone, facilitated lordosis response in ovariectomized $\mathrm{E}_{2}$-primed female rats [122-125]. Since ring-A reduced progestins have decreased affinity for the PRs, direct PR binding is probably not involved in this response. Furthermore, inhibition of this behavioral response by RU 38486 suggests that pathways antagonized by this compound could be involved in the facilitation of sexual behavior [111, 123, 126]. Accumulating evidence suggests that several of these agents influence female sexual behavior by activating extranuclear protein kinases $\mathrm{A}$ and $\mathrm{C}$ (PKA, PKC), calcium and calmodulin kinase II (CaMKII), and mitogen-activated protein kinase (MAPK) in the $\mathrm{VMH}$ and POA in the female rat $[30,74,111,127-137]$.

\section{Integration of Mechanisms}

Studies to date have identified a high degree of crosstalk between various kinase-initiated pathways (by neurotransmitters, nucleotides and neuropeptides) and nuclear PRs in the brain, suggesting that integration of both rapid membrane and slower genomic actions is an essential component of female sexual behavior. A model depicting the interactions is shown in figure 2. Classical actions of $\mathrm{P}$, mediated by intracellular PRs functioning as transcription factors, remain the primary mechanism of $P$ action in female sex behavior $[65,90]$.

Nonclassical activation of cytoplasmic signaling pathways, mediated by kinases, whether initiated by nonsteroidal agents or by progestins, can affect both transcription-dependent and -independent actions [94, 138-142]. Interactions between membrane-initiated signaling pathways and intracellular classical PRs resulting in transcription-dependent actions have been demonstrated in the ligand-independent activation of PRs by various fac- 


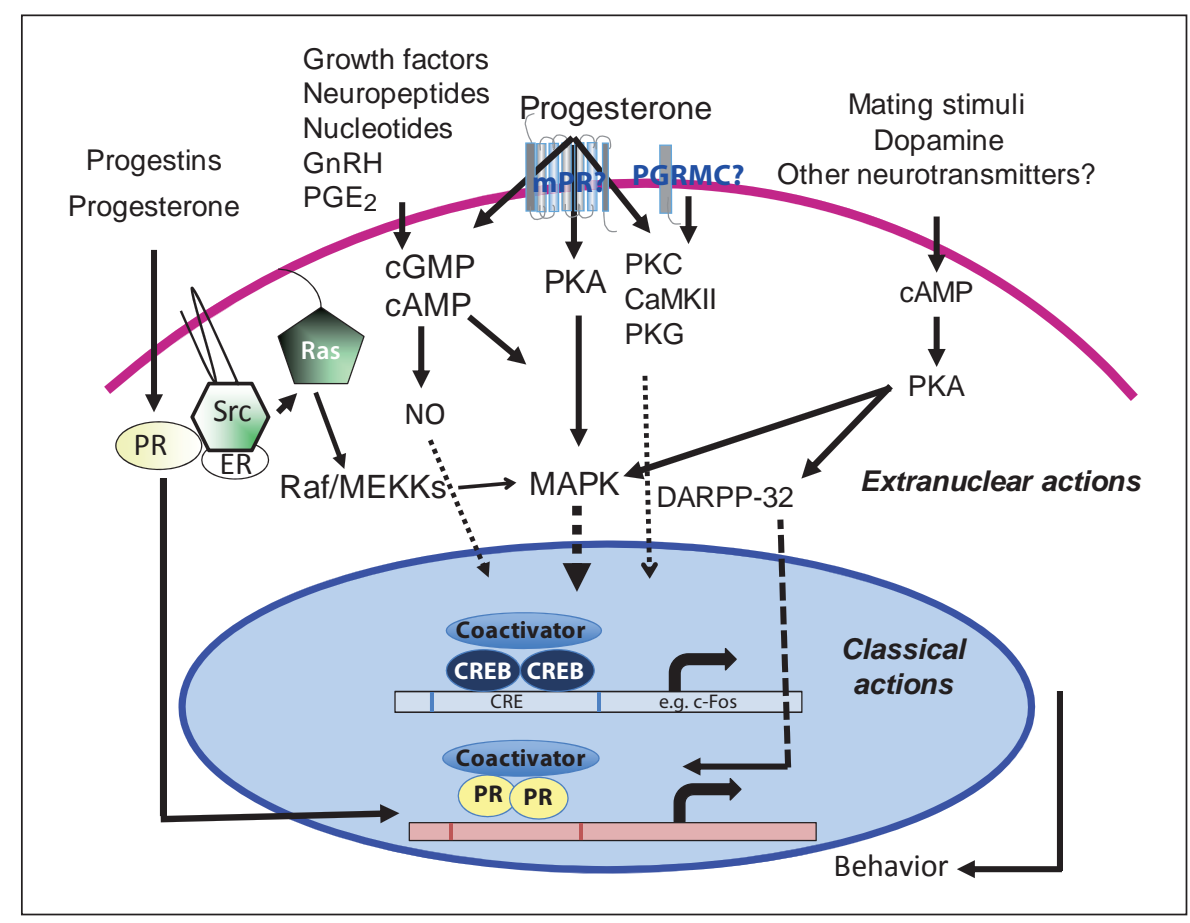

Fig. 2. A schematic representation of the crosstalk between classical and nonclassical mechanisms in female reproductive behavior. The classical mechanism of action by progesterone- and ring-A class of progestins, mediated by classical PRs, promotes interactions with coactivators and plays a predominant role. Progesterone effects mediated by second messengers (cAMP, cGMP) and extranuclear signaling kinases (PKA, PKC, PKG, CaMKII) activates MAPK signal transduction cascade, phosphorylation of nuclear transcription factors, PRs/PR coactivators and CREB. Progesterone and progestins can act via the Src kinase and interact with extranuclear PRs to activate MAPK cascade. Progesterone acting via the extranuclear PKA/MAPK/DARPP-32 pathway can cause a de- crease in phosphatase activity and an increase in phosphorylation of PR and/or its coactivators. Mating stimuli (VCS), dopamine or other neurotransmitters can stimulate PKA activation, phosphorylates DARPP-32, leading to the activation of CREB/PR/coactivators. VCS-stimulated PKA activation can also interact with MAPK cascade. Neuropeptides, nucleotides, growth factors, GnRH, and $\mathrm{PGE}_{2}$ can act through various receptor- and/or second messengers (cAMP, cGMP, NO) and transmit signals to the nuclear PRs or other transcription factors. Interactions between multiple pathways may serve as an amplification mechanism to converge on nuclear transcription factors and/or coactivators to regulate gene transcription and translation, to facilitate female sex behavior. tors $[82,111,123]$. Transcription-independent response of PR has been reported to involve the interaction of membrane-initiated signaling cascade Src/Ras/Raf/MAPK with the Src homology3 (SH3) domain of Src tyrosine kinases through the PXXXP motif at the N-terminal domain of PRs [140]. Recently, Gonzalez-Flores et al. [30] reported that a specific inhibitor of the Src kinase family blocked P-facilitated sex behavior in $\mathrm{E}_{2}$-primed rats. While this study suggests that Src kinase could be involved, its activation and interactions with PRs in mediating transcription-independent actions remain unknown. The downstream mechanisms could involve gene expression via multiple transcription factors or transcription coactivators $[143,144]$. $\mathrm{P}$ has been shown to induce transcription of immediate early genes containing CRE-sequences such as c-fos and c-jun [145] to regulate downstream gene expression by acting on target AP-1 DNA recognition sequences near promoter elements. In addition, integration of the signaling pathways could occur at the level of steroid receptor coregulators through phosphorylation of coactivators [141].

\section{Conclusion}

The original two-step classical model of PR activation has undergone substantial modifications and evolved into a highly complex integrative model involving multiple signaling pathways. Recent studies have provided insights into ligand-dependent and ligand-independent mechanisms of receptor activation and a blueprint for the integrative model for PR activation in the regulation of 
female sexual behavior. It is also becoming abundantly clear that multiple intra- and intercellular mechanisms share signaling components that potentially amplify and integrate signals from a variety of stimuli to achieve neuroendocrine integration required for complex behaviors like reproductive behaviors. It will be critical to understand how neuronal kinases and phosphatases, activated by neurotransmitters, regulate the equilibrium between transcriptionally active and inactive states of PRs and their coregulators in relevant areas of the brain that contribute to the regulation of female sexual behavior. Furthermore, the molecular mechanisms by which this equilibrium could be fine-tuned by second and third messen- gers functioning as signal amplifiers remain to be established. Future studies will likely reveal further insights into the mechanisms by which the multiple signals converge and reinforce neuronal responses to environmental and behavioral events to alter steroid hormone effects on female reproductive behavior.

\section{Acknowledgements}

Work from the authors' laboratories was supported by the following United States Public Health Service grants from the National Institutes of Health: HD062512, MH57442 and MH63954 (S.K.M.) and NS19327 (J.D.B.).

\section{References}

1 Boling J, Young WC, Dempsey EW: Miscellaneous experiments on the estrogen progesterone induction of heat in the spayed guinea pig. Endocrinology 1938;23:182-187.

2 Collins VJ, Boling JI, Dempsey EW, Young WC: Quantitative studies of experimentally induced sexual receptivity in the spayed guinea pig. Endocrinology 1938;23:188-196.

$>3$ Dempsey EW, Hertz R, Young WC: The experimental induction of oestrus (sexual receptivity) in the normal and ovariectomized guinea pig. Am J Physiol 1936;116:201-209.

-4 Boling JL, Blandau RJ: The estrogen-progesterone induction of mating responses in the spayed female rat. Endocrinology 1939;25: 359-364.

5 Ring JR: The estrogen-progesterone induction of sexual receptivity in the spayed female mouse. Endocrinology 1944;34:269275 .

6 Beach FA: Historical origins of modern research on hormones and behavior. Horm Behav 1981;15:325-376.

-7 Feder HH, Resko JA, Goy RW: Progesterone concentrations in the arterial plasma of guinea pigs during the oestrous cycle. J Endocrinol 1968;40:505-513.

-8 Feder HH, Resko JA, Goy RW: Progesterone levels in the arterial plasma of pre-ovulatory and ovariectomized rats. J Endocrinol 1967; 41:563-569.

-9 Butcher RL, Collins WE, Fugo NW: Plasma concentration of $\mathrm{LH}, \mathrm{FSH}$, prolactin, progesterone and estradiol-17 $\beta$ throughout the 4 -day estrous cycle of the rat. Endocrinology 1974;94:1704-1708.

10 Smith MS, Freeman ME, Neill JD: The control of progesterone secretion during the estrous cycle and early pseudopregnancy in the rat: prolactin, gonadotropin and steroid levels associated with rescue of the corpus luteum of pseudopregnancy. Endocrinology 1975;96:219-226.
Lisk RD: A comparison of the effectiveness of intravenous, as opposed to subcutaneous, injection of progesterone for the induction of estrous behavior in the rat. J Biochem Physiol 1960;38:1381-1383.

12 Meyerson B: Latency between intravenous injection of progestins and the appearance of estrous behavior in estrogen-treated ovariectomized rats. Horm Behav 1972;3:1-9.

13 McGinnis MY, Parsons B, Rainbow TC, Krey LC, McEwen BS: Temporal relationship between cell nuclear progestin receptor levels and sexual receptivity following intravenous progesterone administration. Brain Res 1981;218:365-371.

14 Glaser JH, Rubin BS, Barfield RJ: Onset of the receptive and proceptive components of feminine sexual behavior in rats following the intravenous administration of progesterone. Horm Behav 1983;17:18-27.

15 Feder HH, Marrone BL: Progesterone: its role in the central nervous system as a facilitator and inhibitor of sexual behavior and gonadotropin release. Ann NY Acad Sci 1977;286:331-354.

16 Blaustein JD, Wade GN: Progestin binding by brain and pituitary cell nuclei and female rat sexual behavior. Brain Res 1978;140:360367.

17 Moguilewsky M, Raynaud JP: Progestin binding sites in the rat hypothalamus pituitary and uterus. Steroids 1977;30:99-109.

18 Kato J: The role of hypothalamic and hypophyseal 5a-dihydrotestosterone, estradiol and progesterone receptors in the mechanism of feedback action. J Ster Biochem 1975; 6:979-987.

19 Kato J, Onouchi T: Specific progesterone receptors in the hypothalamus and anterior hypophysis of the rat. Endocrinology 1977; 101:920-928.
20 Seiki K, Hattori M: In vivo uptake of progesterone by the hypothalamus and pituitary of the female ovariectomized rat and its relationship to cytoplasmic progesterone-binding protein. Endocrinol Jpn 1973;20:111-119.

21 Sar M, Stumpf WE: Neurons of the hypothalamus concentrate $\left[{ }^{3} \mathrm{H}\right]$ progesterone or its metabolites. Science 1973;183:1266-1268.

22 Warembourg M: Radioautographic study of the brain and pituitary after $\left[{ }^{3} \mathrm{H}\right]$ progesterone injection into estrogen-primed ovariectomized guinea pigs. Neurosci Lett 1978;7: $1-5$.

23 MacLusky NJ, McEwen BS: Oestrogen modulates progestin receptor concentrations in some rat brain regions but not in others. $\mathrm{Na}$ ture 1978;274:276-278.

-24 Blaustein JD, Feder HH: Cytoplasmic progestin receptors in guinea pig brain: characteristics and relationship to the induction of sexual behavior. Brain Res 1979;169:481497.

25 Blaustein JD, Feder HH: Cytoplasmic progestin receptors in female guinea pig brain and their relationship to refractoriness in expression of female sexual behavior. Brain Res 1979;177:489-498

26 Moguilewsky M, Raynaud JP: The relevance of hypothalamic and hypophyseal progestin receptor regulation in the induction and inhibition of sexual behavior in the female rat. Endocrinology 1979;105:516-522.

27 Parsons B, McEwen BS, Pfaff DW: A discontinuous schedule of estradiol treatment is sufficient to activate progesterone-facilitated feminine sexual behavior and to increase cytosol receptors for progestins in the hypothalamus of the rat. Endocrinology 1982;110: 613-624.

28 Parsons B, MacLusky NJ, Krey L, Pfaff DW, McEwen BS: The temporal relationship between estrogen-inducible progestin receptors in the female rat brain and the time course of estrogen activation of mating behavior. Endocrinology 1980;107:774-779. 
29 Parsons B, McGinnis MY, McEwen BS: Sequential inhibition by progesterone: effects on sexual receptivity and associated changes in brain cytosol progestin binding in the female rat. Brain Res 1981;221:149-160.

- 30 Gonzalez-Flores O, Beyer C, Gomora-Arrati P, Garcia-Juarez M, Lima-Hernandez FJ, Soto-Sanchez A, Etgen AM: A role for Src kinase in progestin facilitation of estrous behavior in estradiol-primed female rats. Horm Behav 2010;58:223-229.

- 31 King WJ, Greene GL: Monoclonal antibodies localize oestrogen receptor in the nuclei of target cells. Nature 1984;307:745-747.

- 32 Welshons WV, Lieberman ME, Gorski J: Nuclear localization of unoccupied oestrogen receptors. Nature 1984;307:747-749.

-33 Blaustein JD, Feder HH: Nuclear progestin receptors in guinea pig brain measured by and in vitro exchange assay after hormonal treatments that affect lordosis. Endocrinology 1980;106:1061-1069.

- 34 Brown TJ, Blaustein JD: Supplemental progesterone delays heat termination and loss of progestin receptors from hypothalamic cell nuclei in female guinea pigs. Neuroendocrinology 1984;39:384-391.

- 35 Brown TJ, Blaustein JD: Loss of hypothalamic nuclear-bound progestin receptors: Factors involved and the relationship to heat termination in female guinea pigs. Brain Res 1985;358:180-190.

-36 Brown TJ, Blaustein JD: Abbreviation of the period of sexual behavior in female guinea pigs by the progesterone antagonist, RU 486 . Brain Res 1986;373:103-113.

-37 Warembourg M: Radioautographic study of the rat brain, uterus and vagina after $\left[{ }^{3} \mathrm{H}\right]$ R-5020 injection. Mol Cell Endocrinol 1978; 12:67-79.

- 38 Warembourg M: Uptake of ${ }^{3} \mathrm{H}$ labeled synthetic progestin by rat brain and pituitary. A radioautography study. Neurosci Lett 1978; 9:329-332.

-39 Parsons B, Rainbow TC, MacLusky NJ, McEwen BS: Progestin receptor levels in rat hypothalamic and limbic nuclei. J Neurosci 1982;2:1446-1452.

-40 Thornton JE, Nock B, McEwen BS, Feder $\mathrm{HH}$ : Estrogen induction of progestin receptors in microdissected hypothalamic and limbic nuclei of female guinea pigs. Neuroendocrinology 1986;43:182-188.

-41 Rainbow TC, Parsons B, MacLusky NJ, McEwen BS: Estradiol receptor levels in rat hypothalamic and limbic nuclei. J Neurosci 1982; 2:1439-1445.

-42 Warembourg M, Logeat F, Milgrom E: Immunocytochemical localization of progesterone receptor in the guinea pig central nervous system. Brain Res 1986;384:121-131.

-43 Blaustein JD, King JC, Toft DO, Turcotte J: Immunocytochemical localization of estrogen-induced progestin receptors in guinea pig brain. Brain Res 1988;474:1-15.
44 Blaustein JD, Turcotte JC: Estradiol-induced progestin receptor immunoreactivity is found only in estrogen receptor-immunoreactive cells in guinea pig brain. Neuroendocrinology 1989;49:454-461.

45 Warembourg M, Jolivet A, Milgrom E: Immunohistochemical evidence of the presence of estrogen and progesterone receptors in the same neurons of the guinea pig hypothalamus and preoptic area. Brain Res 1989; 480:1-15.

46 Turcotte JC, Blaustein JD: Immunocytochemical localization of midbrain estrogen receptor-containing and progestin receptorcontaining cells in female guinea pigs. J Comp Neurol 1993;328:76-87.

47 DonCarlos LL, Greene GL, Morrell JI: Estrogen plus progesterone increases progestin receptor immunoreactivity in the brain of ovariectomized guinea pigs. Neuroendocrinology 1989;50:613-623.

- 48 Waters EM, Torres-Reveron A, McEwen BS, Milner TA: Ultrastructural localization of extranuclear progestin receptors in the rat hippocampal formation. J Comp Neurol 2008;511:34-46.

49 Mitterling KL, Spencer JL, Dziedzic N, Shenoy S, McCarthy K, Waters EM, McEwen BS, Milner TA: Cellular and subcellular localization of estrogen and progestin receptor immunoreactivities in the mouse hippocampus. J Comp Neurol 2010;518:2729-2743.

50 Delville Y, Blaustein JD: A site for estradiol priming of progesterone-facilitated sexual receptivity in the ventrolateral hypothalamus of female guinea pigs. Brain Res 1991; 559:191-199.

51 Intlekofer KA, Petersen SL: Distribution of mRNAs encoding classical progestin receptor, progesterone membrane components 1 and 2 , serpine mRNA binding protein 1 , and progestin and ADIPOQ receptor family members 7 and 8 in rat forebrain. Neuroscience 2011;172:55-65.

52 Kastner P, Krust A, Turcotte B, Stropp U, Tora L, Gronemeyer H, Chambon P: Two distinct estrogen-regulated promoters generate transcripts encoding the two functionally different human progesterone receptor forms A and B. EMBO J 1990;9:1603-1614.

53 Conneely OM, Kettelberger DM, Tsai MJ, Schrader WT, O'Malley BW: The chicken progesterone receptor $\mathrm{A}$ and $\mathrm{B}$ isoforms are products of an alternate translation initiation event. J Biol Chem 1989;264:1406214064.

54 Giangrande PH, Kimbrel A, Edwards DP, McDonnell DP: The opposing transcriptional activities of the two isoforms of the human progesterone receptor are due to differential cofactor binding. Mol Cell Biol 2000;20:3102.

55 Kato J, Hirata S, Nozawa A, Yamadamouri N: Gene expression of progesterone receptor isoforms in the rat brain. Horm Behav 1994; 28:454-463.

56 Camacho-Arroyo I, Guerra-Araiza C, Cerbon MA: Progesterone receptor isoforms are differentially regulated by sex steroids in the rat forebrain. Neuroreport 1998;9:3993-3996.
57 Guerra-Araiza C, Cerbon MA, Morimoto S, Camacho-Arroyo I: Progesterone receptor isoforms expression pattern in the rat brain during the estrous cycle. Life Sci 2000;66: 1743-1752.

58 Guerra-Araiza C, Villamar-Cruz O, Gonzalez-Arenas A, Chavira R, Camacho-Arroyo I: Changes in progesterone receptor isoforms content in the rat brain during the oestrous cycle and after oestradiol and progesterone treatments. J Neuroendocrinol 2003;15:984990.

59 Scott EM, Wu-Peng S, Pfaff DW: Regulation and expression of progesterone receptor mRNA isoforms $\mathrm{A}$ and $\mathrm{B}$ in the male and female rat hypothalamus and pituitary following oestrogen treatment. J Neuroendocrinol 2002;14:175-183.

60 Mendoza-Garces L, Camacho-Arroyo I, Cerbon MA: Effects of mating on progesterone receptor isoforms in rat hypothalamus. Neuroreport 2010;21:513-516.

61 Mani SK, Reyna AM, Chen JZ, Mulac-Jericevic B, Conneely OM: Differential response of progesterone receptor isoforms in hormone-dependent and -independent facilitation of female sexual receptivity. Mol Endocrinol 2006;20:1322-1332.

62 O'Malley BW: Coregulators: from whence came these 'master genes'. Mol Endocrinol 2007;21:1009-1013.

-63 Onate SA, Tsai SY, Tsai MJ, O’Malley BW: Sequence and characterization of a coactivator for the steroid hormone receptor superfamily. Science 1995;270:1354-1357.

-64 Molenda HA, Griffin AL, Auger AP, McCarthy MM, Tetel MJ: Nuclear receptor coactivators modulate hormone-dependent gene expression in brain and female reproductive behavior in rats. Endocrinology 2002;143: 436-444.

65 Molenda-Figueira HA, Williams CA, Griffin AL, Rutledge EM, Blaustein JD, Tetel MJ: Nuclear receptor coactivators function in estrogen receptor- and progestin receptor-dependent aspects of sexual behavior in female rats. Horm Behav 2006;50:383-392.

66 Molenda-Figueira HA, Murphy SD, Shea KL, Siegal NK, Zhao Y, Chadwick JG Jr, Denner LA, Tetel MJ: Steroid receptor coactivator-1 from brain physically interacts differentially with steroid receptor subtypes. Endocrinology 2008; 149:5272-5279.

67 Yore MA, Im D, Webb LK, Zhao Y, Chadwick JG Jr, Molenda-Figueira HA, Haidacher SJ, Denner L, Tetel MJ: Steroid receptor coactivator-2 expression in brain and physical associations with steroid receptors. Neuroscience 2010;169:1017-1028.

68 Tetel MJ, Siegal NK, Murphy SD: Cells in behaviourally relevant brain regions coexpress nuclear receptor coactivators and ovarian steroid receptors. J Neuroendocrinol 2007; 19:262-271.

- 69 Blaustein JD, Lehman MN, Turcotte JC, Greene G: Estrogen receptors in dendrites and axon terminals in the guinea pig hypothalamus. Endocrinology 1992;131:281-290. 
70 Blaustein JD, Olster DH: Colchicine-induced accumulation of estrogen receptor and progestin receptor immunoreactivity in atypical areas in guinea-pig brain. J Neuroendocrinol 1993;5:63-70.

71 Debold JF, Frye CA: Genomic and non-genomic actions of progesterone in the control of female hamster sexual behavior. Horm Behav 1994;28:445-453.

-72 Moss RL, McCann SM: Induction of mating behavior in rats by luteinizing hormone-releasing factor. Science 1973;181:177-179.

73 Rodriguez-Sierra JF, Komisaruk BR: Effects of prostaglandin $\mathrm{E}_{2}$ and indomethacin on sexual behavior in the female rat. Horm Behav 1977;9:281-289.

-74 Beyer C, Gonzalez-Mariscal G: Elevation in hypothalamic cyclic AMP as a common factor in the facilitation of lordosis in rodents: a working hypothesis. Ann NY Acad Sci 1986; 474:270-281.

-75 Beyer C, Gonzalez-Flores O, Garcia-Juarez M, Gonzalez-Mariscal G: Non-ligand activation of estrous behavior in rodents: crosstalk at the progesterone receptor. Scand J Psychol 2003;44:221-229.

76 Pfaff DW, Schwartz-Giblin S, McCarthy MM, Kow L-M: Cellular and molecular mechanisms of female reproductive behaviors; in Knobil E, Neill JD, (eds): The Physiology of Reproduction. New York, Raven Press, 1994, pp 107-220.

-77 Kimura F, Kawakami M, Nakano H, McCann SM: Changes in adenosine $3^{\prime}, 5^{\prime}$ monophosphate and guanosine $3^{\prime}, 5^{\prime}$ monophosphate concentrations in the anterior pituitary and hypothalamus during the rat estrous cycle and effects of administration of sodium pentobarbital in proestrus. Endocrinology 1980;106:631-635.

78 Zubin P, Taleisnik S: Hypothalamic cyclicAMP throughout the 4-day estrous cycle of the female rat. Brain Res 1983;271:273-277.

-79 Brown CG, Poyser NL: Studies on the control of prostaglandin production by the hypothalamus in relation to $\mathrm{LH}$ release in the rat. J Endocrinol 1984;103:155-164.

80 Freeman ME: The neuroendocrine control of the ovarian cycle of the rat; in Knobil E, Neill JD, (eds): The Physiology of Reproduction. New York, Raven Press Ltd, 1994, pp 613-658.

81 Etgen AM, Morales JC: Somatosensory stimuli evoke norepinephrine release in the anterior ventromedial hypothalamus of sexually receptive female rats. J Neuroendocrinol 2002;14:213-218.

82 Mani S, Portillo W: Activation of progestin receptors in female reproductive behavior: interactions with neurotransmitters. Front Neuroendocrinol 2010;31:157-171.

83 Meisel RL, Pfaff DW: RNA and protein synthesis inhibitors: effects on sexual behavior in female rats. Brain Res Bull 1984;12:187193.

84 Meisel RL, Pfaff DW: Specificity and neural sites of action of anisomycin in the reduction or facilitation of female sexual behavior in rats. Horm Behav 1985;19:237-251.
Rainbow TC, Davis PG, McEwen BS: Anisomycin inhibits the activation of sexual behavior by estradiol and progesterone. Brain Res 1980;194:548-555.

-86 Whalen RE, Gorzalka BB, Debold JF, Quadagno DM, Kan-wha Ho G, Hough JC: Studies on the effects of intracerebral actinomycin D implants on estrogen-induced receptivity in rats. Horm Behav 1974;5:337-343.

87 Mani SK, Blaustein JD, Allen JM, Law SW, O'Malley BW, Clark JH: Inhibition of rat sexual behavior by antisense oligonucleotides to the progesterone receptor. Endocrinology 1994;135:1409-1414.

88 Pollio G, Xue P, Zanisi M, Nicolin A, Maggi A: Antisense oligonucleotide blocks progesterone-induced lordosis behavior in ovariectomized rats. Mol Brain Res 1993;19:135139.

-89 Ogawa S, Olazabal UE, Parhar IS, Pfaff DW: Effects of intrahypothalamic administration of antisense DNA for progesterone receptor mRNA on reproductive behavior and progesterone receptor immunoreactivity in female rat. J Neurosci 1994;14:1766-1774.

\$0 Mani SK, Allen JMC, Lydon JP, Mulac-Jericevic B, Blaustein JD, DeMayo FJ, Conneely O, O'Malley BW: Dopamine requires the unoccupied progesterone receptor to induce sexual behavior in mice. Mol Endocrinol 1996; 10:1728-1737.

91 Foreman MM, Moss RL: Effects of subcutaneous injection and intrahypothalamic infusion of releasing hormones upon lordotic response to repetitive coital stimulation. Horm Behav 1977;8:219-234.

92 Mani SK, Allen JMC, Clark JH, Blaustein JD, O'Malley BW: Convergent pathways for steroid hormone- and neurotransmitter-induced rat sexual behavior. Science 1994;265: 1246-1249.

93 Mani SK, Fienberg AA, Ocallaghan JP, Snyder GL, Allen PB, Dash PK, Moore AN, Mitchell AJ, Bibb J, Greengard P, O’Malley BW: Requirement for DARPP-32 in progesterone-facilitated sexual receptivity in female rats and mice. Science 2000;287:10531056.

94 Rowan BG, Garrison N, Weigel NL, O’Malley BW: 8-bromo-cyclic AMP induces phosphorylation of two sites in SRC-1 that facilitate ligand-independent activation of the chicken progesterone receptor and are critical for functional cooperation between SRC1 and CREB binding protein. Mol Cell Biol 2000;20:8720-8730.

95 Font de Mora J, Brown M: AIB1 is a conduit for kinase-mediated growth factor signaling to the estrogen receptor. Mol Cell Biol 2000; 20:5041-5047.

96 Lange CA, Gioeli D, Hammes SR, Marker PC: Integration of rapid signaling events with steroid hormone receptor action in breast and prostate cancer. Annu Rev Physiol 2007;69:171-199.

97 Lange CA: Making sense of cross-talk between steroid hormone receptors and intracellular signaling pathways: who will have the last word? Mol Endocrinol 2004;18:269-278.
98 Auger AP, Moffatt CA, Blaustein JD: Progesterone-independent activation of rat brain progestin receptors by reproductive stimuli. Endocrinology 1997;138:511-514.

-99 Auger AP, LaRiccia LM, Moffatt CA, Blaustein JD: Progesterone, but not progesterone-independent activation of progestin receptors by a mating stimulus, rapidly decreases progestin receptor immunoreactivity in female rat brain. Horm Behav 2000; 37:135-144.

100 Auger AP: Ligand-independent activation of progestin receptors: relevance for female sexual behaviour. Reproduction 2001;122 847-855.

101 Bennett AL, Blasberg ME, Blaustein JD: Mating stimulation required for matinginduced estrous abbreviation in female rats: effects of repeated testing. Horm Behav 2002;42:206-211.

102 Kohlert JG, Rowe RK, Meisel RL: Intromissive stimulation from the male increases extracellular dopamine release from fluoro-gold-identified neurons within the midbrain of female hamsters. Horm Behav 1997;32:143-154.

103 Matuszewich L, Lorrain DS, Hull EM: Dopamine release in the medial preoptic area of female rats in response to hormonal manipulation and sexual activity. Behav Neurosci 2000;114:772-782.

104 Mermelstein PG, Becker JB: Increased extracellular dopamine in the nucleus accumbens and striatum of the female rat during paced copulatory behavior. Behav Neurosci 1995; 109:354-365.

105 Vathy I, Etgen AM: Hormonal activation of female sexual behavior is accompanied by hypothalamic norepinephrine release. J Neuroendocrinol 1989;1:383-388.

106 Auger AP, Moffatt CA, Blaustein JD: Reproductively-relevant stimuli induce Fosimmunoreactivity within progestin receptor-containing neurons in localized regions of female rat forebrain. J Neuroendocrinol 1996;8:831-838.

107 Beyer C, Gonzalez-Flores O, GonzalezMariscal G: Progesterone receptor participates in the stimulatory effect of $\mathrm{LHRH}$, prostaglandin $\mathrm{E}_{2}$, and cyclic AMP on lordosis and proceptive behaviours in rats. J Neuroendocrinol 1997;9:609-614.

108 Acosta-Martinez M, Gonzalez-Flores O, Etgen AM: The role of progestin receptors and the mitogen-activated protein kinase pathway in delta opioid receptor facilitation of female reproductive behaviors. Horm Behav 2006;49:458-462.

109 Chu HP, Etgen AM: A potential role of cyclic GMP in the regulation of lordosis behavior of female rats. Horm Behav 1997;32: 125-132.

110 Chu HP, Morales JC, Etgen AM: Cyclic GMP may potentiate lordosis behaviour by progesterone receptor activation. J Neuroendocrinol 1999;11:107-113. 
111 Gonzalez-Flores O, Etgen AM, Komisaruk $>122$ Beyer C, Gonzalez-Mariscal G, Eguibar JR, BK, Gomora-Arrati P, Macias-Jimenez A, Lima-Hernandez FJ, Garcia-Juarez M, Beyer C: Antagonists of the protein kinase A and mitogen-activated protein kinase systems and of the progestin receptor block the ability of vaginocervical/flank-perineal stimulation to induce female rat sexual behaviour. J Neuroendocrinol 2008;20:1361-1367.

-112 Boonyaratanakornkit V, Bi Y, Rudd M, Edwards DP: The role and mechanism of progesterone receptor activation of extra-nuclear signaling pathways in regulating gene transcription and cell cycle progression. Steroids 2008;73:922-928.

-113 Schumacher M, Coirini H, Robert F, Guennoun R, Eletr M: Genomic and membrane actions of progesterone: implications for reproductive physiology and behavior. Behav Brain Res 1999;105:37-52.

-114 Krebs CJ, Jarvis ED, Chan J, Lydon JP, Ogawa S, Pfaff DW: A membrane-associated progesterone-binding protein, $25-\mathrm{Dx}$, is regulated by progesterone in brain regions involved in female reproductive behaviors. Proc Natl Acad Sci USA 2000;97:12816-12821.

- 115 Sleiter N, Pang Y, Park C, Horton TH, Dong J, Thomas P, Levine JE: Progesterone receptor A (PRA) and PRB-independent effects of progesterone on gonadotropin-releasing hormone release. Endocrinology 2009;150: 3833-3844.

116 Intlekofer KA, Petersen SL: 17beta-estradi$\mathrm{ol}$ and progesterone regulate multiple progestin signaling molecules in the anteroventral periventricular nucleus, ventromedial nucleus and sexually dimorphic nucleus of the preoptic area in female rats. Neuroscience 2011;176:86-92.

117 Liu B, Arbogast LA: Gene expression profiles of intracellular and membrane progesterone receptor isoforms in the mediobasal hypothalamus during pro-oestrus. J Neuroendocrinol 2009;21:993-1000.

-118 Zhu Y, Rice CD, Pang YF, Pace M, Thomas $\mathrm{P}$ : Cloning, expression, and characterization of a membrane progestin receptor and evidence it is an intermediary in meiotic maturation of fish oocytes. Proc Natl Acad Sci USA 2003;100:2231-2236.

119 Zhu Y, Bond J, Thomas P: Identification, classification, and partial characterization of genes in humans and other vertebrates homologous to a fish membrane progestin receptor. Proc Natl Acad Sci USA 2003;100: 2237-2242.

120 Falkenstein E, Meyer C, Eisen C, Scriba PC, Wehling M: Full-length cDNA sequence of a progesterone membrane-binding protein from porcine vascular smooth muscle cells. Biochem Biophys Res Commun 1996;229: 86-89.

- 121 Krebs CJ, Jarvis ED, Chan J, Lydon JP, Ogawa S, Pfaff DW: A membrane-associated progesterone-binding protein, $25-\mathrm{Dx}$, is regulated by progesterone in brain regions involved in female reproductive behaviors. Proc Natl Acad Sci USA 2000;97:1281612821. Gomora P: Lordosis facilitation in estrogen primed rats by intrabrain injection of pregnanes. Pharmacol Biochem Behav 1988;31: 919-926.

123 Beyer C, Gonzalez-Flores O, GonzalezMariscal G: Ring A reduced progestins potently stimulate estrous behavior in rats: paradoxical effect through the progesterone receptor. Physiol Behav 1995;58:985-993.

124 Glaser JH, Etgen AM, Barfield RJ: Intrahypothalamic effects of progestin agonists on estrous behavior and progestin receptor binding. Physiol Behav 1985;34:871-877.

125 Gonzalez-Flores O, Ramirez-Orduna JM, Lima-Hernandez FJ, Garcia-Juarez M, Beyer C: Differential effect of kinase A and C blockers on lordosis facilitation by progesterone and its metabolites in ovariectomized estrogen-primed rats. Horm Behav 2006;49:398-404.

126 Gonzalez-Mariscal G, Gonzalez-Flores O, Beyer C: Intrahypothalamic injection of RU 486 antagonizes the lordosis induced by ring A-reduced progestins. Physiol Behav

127 Balasubramanian B, Portillo W, Reyna A, Chen JZ, Moore AN, Dash PK, Mani SK: Nonclassical mechanisms of progesterone action in the brain: I. Protein kinase $\mathrm{C}$ activation in the hypothalamus of female rats. Endocrinology 2008;149:5509-5517.

128 Balasubramanian B, Portillo W, Reyna A, Chen JZ, Moore AN, Dash PK, Mani SK: Nonclassical mechanisms of progesterone action in the brain: II. Role of calmodulindependent protein kinase II in progesterone-mediated signaling in the hypothalamus of female rats. Endocrinology 2008; 149:5518-5526.

129 Chu HP, Morales JC, Etgen AM: Cyclic GMP may potentiate lordosis behaviour by progesterone receptor activation. J Neuroendocrinol 1999;11:107-113.

130 Chu HP, Etgen AM: Ovarian hormone dependence of alpha(1)-adrenoceptor activation of the nitric oxide-cGMP pathway: relevance for hormonal facilitation of lordosis behavior. J Neurosci 1999;19:7191-7197.

131 Kow LM, Mobbs CV, Pfaff DW: Roles of second-messenger systems and neuronal activity in the regulation of lordosis by neurotransmitters, neuropeptides, and estrogen: a review. Neurosci Biobehav Rev 1994; 18:251-268.

132 Petitti N, Etgen AM: Progesterone depression of norepinephrine-stimulated cAMP accumulation in hypothalamic slices. Mol Brain Res 1989;5:109-119.

133 Petitti N, Etgen AM: Alpha-1-adrenoceptor augmentation of beta-stimulated cAMP formation is enhanced by estrogen and reduced by progesterone in rat hypothalamic slices. J Neurosci 1990;10:2842-2849.

134 Etgen AM, Acosta-Martinez M: Participation of growth factor signal transduction pathways in estradiol facilitation of female reproductive behavior. Endocrinology 1989;46:435-438. 2003; 144:3828-3835.
135 Gonzalez-Flores O, Shu J, Camacho-Arroyo I, Etgen AM: Regulation of lordosis by cyclic 3',5'-guanosine monophosphate, progesterone, and its 5alpha-reduced metabolites involves mitogen-activated protein kinase. Endocrinology 2004; 145:55605567.

136 Gonzalez-Flores O, Guerra-Araiza C, Cerbon M, Camacho-Arroyo I, Etgen AM: The $26 \mathrm{~S}$ proteasome participates in the sequential inhibition of estrous behavior induced by progesterone in rats. Endocrinology 2004;145:2328-2336.

137 Gonzalez-Flores O, Gomora-Arrati P, Garcia-Juarez M, Gomez-Camarillo MA, Lima-Hernandez FJ, Beyer C, Etgen AM: Nitric oxide and ERK/MAPK mediation of estrous behavior induced by $\mathrm{GnRH}, \mathrm{PGE}_{2}$ and db-cAMP in rats. Physiol Behav 2009; 96:606-612.

138 Hagan CR, Daniel AR, Dressing GE, Lange CA: Role of phosphorylation in progesterone receptor signaling and specificity. Mol Cell Endocrinol 2012;357:43-49.

139 Proietti C, Salatino M, Rosemblit C, Carnevale R, Pecci A, Kornblihtt AR, Molinolo AA, Frahm I, Charreau EH, Schillaci R, Elizalde PV: Progestins induce transcriptional activation of signal transducer and activator of transcription 3 (Stat3) via a Jakand Src-dependent mechanism in breast cancer cells. Mol Cell Biol 2005;25:48264840 .

140 Boonyaratanakornkit V, Scott MP, Ribon V, Sherman L, Anderson SM, Maller JL, Miller WT, Edwards DP: Progesterone receptor contains a proline-rich motif that directly interacts with $\mathrm{SH} 3$ domains and activates c-Src family tyrosine kinases. Mol Cell 2001;8:269-280.

141 Rowan BG, Weigel NL, O’Malley BW: Phosphorylation of steroid receptor coactivator-1 - Identification of the phosphorylation sites and phosphorylation through the mitogen-activated protein kinase pathway. J Biol Chem 2000;275:4475-4483.

142 Thomas P, Pang Y: Membrane progesterone receptors: evidence for neuroprotective, neurosteroid signaling and neuroendocrine functions in neuronal cells. Neuroendocrinology 2012;96:162-171.

143 Watters JJ, Campbell JS, Cunningham MJ, Krebs EG, Dorsa DM: Rapid membrane effects of steroids in neuroblastoma cells: effects of estrogen on mitogen activated protein kinase signalling cascade and c-fos immediate early gene transcription. Endocrinology 1997;138:4030-4033.

144 Watters JJ, Dorsa DM: Transcriptional effects of estrogen on neuronal neurotensin gene expression involve $\mathrm{cAMP} /$ protein $\mathrm{ki}$ nase A-dependent signaling mechanisms. J Neurosci 1998;18:6672-6680.

145 Auger AP, Blaustein JD: Progesterone treatment increases Fos-immunoreactivity within some progestin receptor-containing neurons in localized regions of female rat forebrain. Brain Res 1997;746:164-170. 